\title{
ИСТОРИЯ РОССИИ НОВЕЙШЕГО ВРЕМЕНИ
}

УДК 336.71(571.51)

DOI: $10.23951 / 1609-624 X-2017-5-22-26$

\section{ПРОБЛЕМЫ РАЗВИТИЯ СБЕРЕГАТЕЛЬНОГО ДЕЛА НА РУБЕЖЕ ХІХ-ХХ ВЕКОВ В ЕНИСЕЙСКОЙ ГУБЕРНИИ}

\author{
Г. М. Лущаева, А. А. Кондратьева \\ Сибирский федеральный университет, Красноярск
}

\begin{abstract}
Рассматривается становление и развитие сберегательных касс в Енисейской губернии, их организация и деятельность в дореволюционный период. Историография сберегательного дела в России достаточно обширна, однако обобщающего исследования по истории сберегательной системы на уровне отдельного региона (в том числе в Енисейской губернии) на сегодняшний день не существует. Дана характеристика Енисейской губернии с позиции социально-экономического развития, обоснование значимости ссудо-сберегательных и кредитных товариществ для региона. Описана роль Енисейской казенной палаты как первичного государственного учреждения в становлении финансового дела региона в дореволюционное время. Данный период характеризует кассы как объекты самопомощи для населения, вследствие чего происходил процесс увеличения их сети. Показано влияние Государственного банка на изменение социально-экономического статуса региона и его роль в финансово-кредитной системе страны. Выявлен особый путь развития сберегательных касс в Енисейской губернии, а также изменение отношения сибиряков к данным видам учреждений. Анализируется эволюция численности сберегательных касс как на российском, так и на региональном уровне, что позволяет оценить перспективы их развития.
\end{abstract}

Ключевые слова: сберегательные кассы, сберегательное дело, вклады, банковское дело, финансовые операции, Енисейская губерния.

Банки играют большую роль в создании рыночной экономики. Гармоничное создание всего банковского сектора обусловлено необходимостью правильного функционирования экономики страны. Немаловажным аспектом в актуальности является экономический кризис, поразивший общество, вызванная им потребность в поиске новых путей реформирования экономики Российской Федерации. На сегодняшний день Сбербанк оказывает большой перечень услуг и операций для удовлетворения нужд населения.

Первые крупные исследования по истории сберегательного дела появились только в 1950-х гг. Так, профессор С. Я. Боровой в своей монографии «Кредит и банки России» подчеркнул главную, на его взгляд, задачу сберегательных касс - «улавливание мелких сбережений для использования их в интересах царского правительства» [1, с. 174]. В советский период отдельные сведения о развитии финансового сектора экономики были представлены также в многотомных фундаментальных работах по истории Сибири.

Качественно новой работой стал вышедший в 1991 г. в честь 150-летнего юбилея альбом «История Сбербанка России. 1841-1991 гг.» под редакцией А. И. Казьмина - президента, являющегося председателем правления Сбербанка России [2].
Комплексным исследованием по истории сберегательных касс дореволюционной России, вышедшим в 1995 г., стала монография «Сберегательное дело в России: вехи истории» Ю. А. Петрова и С. В. Калмыкова [3, с. 364]. В работе отражена связь конкретных исторических событий с развитием российского сберегательного дела.

Таким образом, историки на протяжении полутора веков обращались к проблеме становления и развития сберегательных учреждений Енисейской губернии, однако комплексный анализ сберегательной системы на уровне отдельного региона в отечественной историографии фактически отсутствует.

Для написания статьи использовались документы и материалы Красноярского государственного казенного учреждения «Государственный архив Красноярского края» (КГКУ «ГАКК») - циркуляры заседаний, делопроизводственная документация кредитных учреждений. Материалы датированы серединой XIX в. - 1917 г. и являются важнейшим источником для изучения сберегательного дела в Енисейской губернии в XIX в.

Развитие банковской системы в Енисейской губернии имеет прочную связь с историей развития банковского дела в России. В эпоху складывания 
новых экономических и капиталистических отношений в Российской империи происходит зарождение сберегательных касс. В отличие от европейских стран, где инициаторами были общественные организации и частные лица, основоположником создания сберегательных касс в Российской империи стала власть.

Енисейская губерния являлась краем преимущественно крестьянским, с мелким сельскохозяйственным производством. Поэтому здесь особенно велика была потребность в мелком кредите. Работа по созданию ссудо-сберегательных и кредитных товариществ в губернии проявилась еще мощнее, чем в целом по стране. В сложившихся условиях общенародный кредит в губернии стал необходим как простому крестьянину, так и жителю крупного города. Чиновники Казенной палаты оказывали значительную помощь для развития финансово-кредитных учреждений. Именно вследствие их стараний народный кредит стал массовым явлением.

Именно с такого государственного учреждения, как Енисейская казенная палата, началось становление финансового дела региона. В деятельность палаты входили самые различные обязанности, и не только финансовые. Уездные казначейства, подвластные палате, кассы заведовали приемом и хранением денежных средств, а также производили их выдачу чиновникам, ведали природными ресурсами губернии.

Государственный банк России открыл свои двери 31 мая 1860 г. Предпосылками к его открытию послужили привносимые вклады в частные кредитные учреждения в начале 1850-х гг. По данным на 1 января 1855 г., общая сумма вкладов составляла 873 миллиона рублей, то к середине 1857 года она достигла 1276 миллионов рублей. Как отмечалось в официальных документах тех лет, главной причиной такого скопления средств послужил застой в развитии торгово-промышленных отношений, «частные капиталы не находили себе прибыльного помещения и усиленно притекали в казенные банки» [4, с. 38]. Таким образом, получалось, что деньги не пускались в оборот и оставались без работы, а вклады продолжали свой рост. Правительство пошло на вынужденные меры по понижению процента частных вкладов с 4 до $3 \%$. Государственный банк мог производить различные коммерческие операции: вексельный учет, операции по покупке и продаже золота и серебра, прием вкладов на хранение на текущий счет вкладчика и на обращение из процентов, производство ссуд. Банк находился в прямой зависимости от Министерства финансов.

Красноярское отделение Государственного банка не заставило себя долго ждать и уже через 5 лет, в 1865 г., запустило свою работу. Для такого регио- на, как Енисейская губерния, характеризующегося как провинциальный аграрный регион, данное событие носило весомое значение. С открытием Государственного банка вклады населения вступали в работу, и регион получал возможность участвовать в финансово-кредитной системе страны, и тем самым укреплялись позиции Сибири. Банковское дело в губернии стало процветать, люди охотнее шли на сделку с финансистами.

Особое место среди банковско-кредитных учреждений Енисейской губернии занимали сберегательные кассы, начавшие свою деятельность в губернии с середины 1860-х гг. при отделениях Государственного банка.

Первые знания о сберегательных кассах у жителей Енисейской губернии появились в 1863 г., когда о них появилась статья в газете «Енисейские губернские ведомости». Подлинная дата открытия первой сберкассы в Енисейской губернии до сих пор не выявлена: часть источников указывают на 1866 г., другие - 1867 г. Однозначно следующее целью данных учреждений был «прием небольших сумм на сохранение с приращением процентов» $[5$, c. 3], контингент у касс был разнообразный, люди разных слоев населения отдавали свои деньги на сбережение для будущих нужд.

Деятельность сберегательных касс в начале своего пути была своеобразна. Кассы работали только два дня в неделю по три часа, этими днями стали - среда и воскресенье. На первом этапе развития касс люди не спешили туда со своими вкладами, в обществе присутствовал дух недоверия к данным учреждениям.

В 1872 г. в Красноярске было выдано 16 сберегательных книжек, однако их владельцами по большей части стали лица женского пола. По статистике, в 1867 г. сибиряки доверили сберегательным кассам всего 99 рублей, в 1868 г. и того меньше - 28 рублей, в 1869 г. - 155 рублей, в 1870 г. 47 рублей, в 1871-м - 56 рублей, в 1872-м 200 рублей [5, с. 11]. Стоит отметить, что цифры невелики для нескольких лет работы сберегательных касс.

Постепенно определялся круг деятельности касс: размер единоразовых вкладов был назначен в диапазоне от 50 коп. до 10 руб., общий объем вклада одного лица не должен был превышать 300 руб. серебром [2]. В заимствованном от европейской практики ограничении суммы вклада отразился свойственный той эпохе взгляд на сберегательные кассы как учреждения самопомощи для малоимущих слоев.

Развитие отечественного сберегательного дела в Енисейской губернии с начала своего пути до середины 1870-х гг. было в целом замедленным. Первые годы существования сберегательных касс не 
стали периодом сколько-нибудь значительного их развития. Процесс распространения касс происходил очень медленно, а сумма вложенных вкладчиками денег практически не увеличивалась. Главной причиной тому служила экономическая отсталость региона и недоверие народа на первых порах к данным учреждениям.

Проводимая в 1895 г. денежная реформа, связанная с именем С. Ю. Витте, не обошла стороной сберегательные кассы. Основная суть реформы состояла в неограниченном вмешательстве государства в экономику с переходом к монометаллическому денежному обращению. Вследствие чего пришли к использованию как счетного средства золотого рубля, на работу с которым были переведены сберегательные кассы. Этот шаг имел большое значение для населения, складывание доверительных отношений с теми учреждениями, которые могли помещать их вклады в гарантированные золотом билеты Государственного банка. Для того чтобы привлечь на сторону касс большее число клиентов, правительством был принят специальный закон о переводе касс в категорию государственных учреждений. Теперь правительство полностью отвечало за сохранность вкладов в кассах, что увеличивало как финансовую мощь, так и роль государства в экономике.

По состоянию на 1 января 1899 г. в России насчитывалось более 5 тысяч касс. В это время государственные сберкассы открываются в селах Енисейской губернии: Новоселове, Каратузском, Курагино, Уяре, Балахте, Назарово, Ужуре, Кежме, Казачинском, Богучанах, Большемуртинском, Шилинском [6, л. 70].

С 1 января 1894 г. сберегательные кассы начали открываться на почтах и телеграфах [7, л. 67], но чтобы данные места стали рентабельными, правительство пошло на меры по увеличению предельной суммы до 50 рублей [7, л. 83]. Еще одной мерой по завоеванию популярности у населения стал выпуск листовок о сберегательных кассах, в которых прописывались все преимущества и удобство данных учреждений. Основным распространителем являлся Государственный банк: каждому приходящему вкладчику вручали буклеты с основной информацией по работе касс. Особенно это пропагандировалось в сельской, волостной местностях, где основной группой населения являлись учителя школ, родители, рабочие фабрик и заводов [7, л. 86].

В целом приспосабливаемость сберегательных касс к условиям губернии на рубеже XIX-XX вв. показывает превосходство темпов и объемов роста над количеством сберегательных учреждений, в результате в середине 1890-х гг. сберегательные кассы превзошли другие кредитные учреждения, как государственные, так и частные.
Кризис сберегательных касс пришелся на 1900 г. В этом году кассы понесли значительные убытки от переоценки принадлежащих им процентных бумаг. Тем не менее доверие публики не было поколеблено. Для Енисейской губернии были характерны те же тенденции, что и в целом по России.

\section{Развитие сберегательного дела в России в 1900-1915 г2. [8, л. 60]}

\begin{tabular}{|c|c|c|c|c|}
\hline \multirow{2}{*}{$\begin{array}{c}\text { Дан- } \\
\text { ные на } \\
\text { конец } \\
\text { года }\end{array}$} & \multicolumn{2}{|c|}{$\begin{array}{c}\text { Число сберегатель- } \\
\text { ных касс }\end{array}$} & \multicolumn{2}{|c|}{$\begin{array}{c}\text { Количество сберегательных } \\
\text { книжек, тыс. шт. }\end{array}$} \\
\hline & $\begin{array}{l}\text { Россий- } \\
\text { ская } \\
\text { империя }\end{array}$ & \begin{tabular}{|c|} 
Енисей- \\
ская \\
губерния
\end{tabular} & $\begin{array}{c}\text { Россий- } \\
\text { ская } \\
\text { империя }\end{array}$ & $\begin{array}{c}\text { Енисейская } \\
\text { губерния }\end{array}$ \\
\hline 1900 & 5415 & Нет св. & 3551 & Нет св. \\
\hline 1904 & 6558 & Нет св. & 5127 & Нет св. \\
\hline 1906 & 6679 & 29 & 5665 & 50 \\
\hline 1910 & 7365 & 43 & 7436 & Het \\
\hline 1913 & 8553 & 50 & 8992 & Нет св. \\
\hline 1914 & 9053 & 112 & 9241 & Нет св. \\
\hline 1915 & 9855 & 126 & 9985 & Нет св. \\
\hline
\end{tabular}

Острый политический кризис, сопряженный с действиями Русско-японской войны 1904-1905 гг. и первой российской революцией, иначе отразился на положении сберегательных касс. Слухи об осложнениях с выдачей вкладов на начало 1900-х гг. постоянно будоражили русскую публику. Это негативно сказалось на капиталах сберегательных касс. Первыми отреагировали вкладчики-иностранцы, которые изымали свои вклады и переправляли их на родину.

Примерно в это время, в 1907 г., участились случаи мошенничества населением, имели место случаи подложного истребования сберегательных книжек. Многие деятели подобных махинаций получали вклады дважды, чем приносили большие убытки сберегательным кассам. 5 марта 1907 г. в Енисейскую казенную палату пришло извещение с требованием «об истребовании от вкладчиков удостоверения личности при выдаче дубликатов сберегательных книжек» [9, л. 43].

Вернуть клиентов в кассы помогло увеличение процентной ставки с 3,6 \% до 4 \% в 1906 г. К 1912 г. сеть банковско-кредитных учреждений Енисейской губернии включала в себя 5 сберкасс Красноярского отделения Госбанка, 43 сберегательные кассы пяти казначейств, 5 общественных банков, 79 кредитных товариществ, 2 ссудо-сберегательных товариществ, 81 земскую кассу [8, л. 60].

В июле 1912 г. с согласия Управляющего Почт и Телеграфа произошло открытие сберегательной кассы при почтовом отделении в с. Идринское Минусинского уезда Енисейской губернии [9, л. 33]. В следующем месяце произошло открытие сберегательных касс в с. Ирбейское Енисейской губернии Канского уезда и в с. Покровское Енисейской губернии Ачинского уезда [9, л. 33 об.]. 
Еще одной проверкой на прочность сберегательных касс послужило объявление Германией войны России. Вкладчикам, оказавшимся в полосе боевых действий, предоставлялось право получить свой взнос в других центральных кассах. Призванные на войну мужчины, озабоченные будущим своих семей, получили право словесно заявлять о переходе вклада в случае их гибели к жене и детям.

4 декабря 1915 г. вышло постановление «О предоставлении на время текущей войны несовершеннолетним, досрочно призванным на военную службу, писать распорядительное завещание над своими вкладами, а также самостоятельно распоряжаться вкладами» [10, л. 64].

Для солдат и офицеров действующей армии организованы были кассы при полевых казначействах, причем по вкладам указывались наследники, которым переводились деньги в случае гибели собственника счета, порой вклады выдавались даже без предъявления книжки.

Таким образом, сберегательные кассы продемонстрировали необыкновенную дееспособность в тяжелые для себя времена приспосабливаться к нелегким экономическим условиям. Немалую роль, конечно, в этом сыграли рабочие кассы, справлявшиеся с большими трудностями и способные аккумулировать средства населения на нужды страны. К концу 1916 г. во многих уголках Енисейской губернии набирали обороты кассы такого рода, решая важные финансовые вопросы населения.

Тем не менее к началу XX в. Енисейская губерния располагала достаточно разветвленной сетью кредитных учреждений различных типов. Начало формирования банковско-кредитных институтов здесь затянулось по сравнению с европейской Россией. Сдержи- вающими факторами выступали экономические, культурные, бытовые особенности региона. Изучение исторических корней сберегательных касс в регионе и стране в целом может помочь исследователям и практикам в оценке перспектив их развития.

Таким образом, на протяжении длительного периода времени сберегательные кассы меняли свой статус и идеологию. Сберегательные кассы в дореформенный период только начинали прокладывать свой путь, набирать обороты. Денежные вклады приобретали огромную популярность, и дореволюционная жизнь сберегательных касс была весьма успешной. Однако небольшая часть населения смогла оценить выгодность и удобство данных учреждений.

С учреждением в 1860 г. Государственного банка России произошли весомые изменения в системе сберегательных касс. Произошла их передача в ведение Министерства финансов, в связи с этим произошло переустройство кредитной системы России на западный лад.

В этот период времени сберегательные кассы только начинают свой путь в Енисейской губернии, однако уже на первых порах в их деятельности можно было наблюдать значительные успехи. Губерния не стала исключением в успешности создания ссудо-сберегательных касс при различных ведомствах, управлениях и учреждениях. Быстрое развитие данных учреждений в сельской местности показало их состоятельность как экономически важных организаций. Тем не менее в Енисейской губернии у населения не сложилось полного доверия к сберегательным кассам. Однако кассы достойно проявили себя в годы войн и революции. Сегодня Сбербанк России - признанный лидер банковской системы с обширной филиальной сетью.

\section{Список источников и литературы}

1. Боровой С. Я. Кредит и банки России (середина XVII в. - 1861 г.). М.: Госфиниздат, 1958. 288 с.

2. Казьмин А. И. История Сбербанка России. М.: СБ РФ, 1991. URL: http://sberbank-history.ru/ (дата обращения: 22.08.2016).

3. Петров Ю. А., Калмыков А. Н. Сберегательное дело в России: вехи истории. М.: К.И.Т., 1995. 364 с.

4. Бердников Л. П., Лонина С. Л. От денежной кладовой до Министерства финансов: очерки истории административно-хозяйственного управления Енисейской губернии Красноярского края (1822-2009). Ч. 1: Столетний путь Енисейской казенной палаты. Красноярск: Издание Министерства финансов Красноярского края, 2009. 262 с.

5. Кауфман И. И. Статистика городских сберегательных касс. СПб., 1875. 110 с.

6. Краевое государственное казенное учреждение «Государственный архив Красноярского края» (КГКУ «ГАКК»). Ф. 606. Оп. 1. Д. 1.

7. КГКУ «ГАКК». Ф. 606. Оп. 1. Д. 68.

8. КГКУ «ГАКК». Ф. 160. Оп. 1. Д. 1686.

9. КГКУ «ГАКК». Ф. 160. Оп. 1. Д. 2145.

10. КГКУ «ГАКК». Ф. 160. Оп. 1. Д. 2452.

Лущаева Галина Михайловна, кандидат исторических наук, доцент, Сибирский федеральный университет (пр. Свободный, 82a, Красноярск, Россия, 660041). E-mail: lusgalina@yandex.ru

Кондратьева Анастасия Александровна, магистр, Сибирский федеральный университет (пр. Свободный, 82а, Красноярск, Россия, 660041). E-mail: nastyaalex010493@mail.ru 
DOI: $10.23951 / 1609-624 X-2017-5-22-26$

\title{
THE PROBLEMS OF DEVELOPMENT OF THE SAVING BUSINESS AT THE TURN OF THE XIX-XX CENTURY IN THE YENISEI PROVINCE
}

\author{
G. M. Lushchaeva, A. A. Kondrat eva
}

Siberian Federal University, Krasnoyarsk, Russian Federation

The article discusses the establishment and development of saving banks in the Yenisei province, their organization and activities in pre-revolutionary time. Historiography of savings business in Russia is quite extensive, but there are no summarizing research on the history of the savings system at the level of a particular region (including the Yenisei province). It characterizes of the Yenisei province from the position of socioeconomic development and justification of the importance of savings and credit partnerships for the region. It describes the role of the Yenisei Treasury Chamber as the primary state institution in the formation of the financial affairs of the region in the pre-revolutionary period. This period characterizes savings banks as a self-help facility for people, so that there was a process of increasing it's network. Represents the influence of the State Bank on the socioeconomic status of the region and its role in the financial and credit system of the country. It reveals a special way of development of savings banks in the Yenisei province and changing the attitude of Siberians towards these types of institutions. Analyzes the evolution of the number of savings banks both on Russian and regional level, as a result it makes it possible to talk about the assessment of their development prospects.

Key words: savings banks, business savings, deposits, banking, financial transactions, Yenisei province.

\section{References}

1. Borovoy S. Ya. Kredit i banki Rossii (seredina XVII v. - 1861 g.) [Credit and Russian banks (mid XVII - 1861)]. Moscow, Gosfinizdat Publ., 1958. 288 p. (in Russian)

2. Kaz'min A. I. Istoriya Sberbanka Rossii [History of Sberbank of Russia]. Moscow, SB RF Publ., 1991 (in Russian). URL: http://sberbank-history. $\mathrm{ru} /$ (accessed 22.08. 2016).

3. Petrov Yu. A., Kalmykov A. N. Sberegatel'noye delo v Rossii: vekhi istorii [Savings business in Russia: milestones]. Moscow, Aktsioner. Kompaniya «K.I.T.» Publ., 1995. 364 p. (in Russian).

4. Berdnikov L. P., Lonina S. L. Ot denezhnoy kladovoy do Ministerstva finansov: ocherki istorii administrativno-khozyaystvennogo upravleniya Eniseyskoy gubernii Krasnoyarskogo kraya (1822-2009). Ch. 1. Stoletniy put' Eniseyskoy kazennoy palaty [From the monetary pantry to the Ministry of Finance: essays on the history of administrative management of the Yenisei province of Krasnoyarsk Territory (1822-2009). Part 1. Centenary of the Yenisey path of the exchequer]. Krasnoyarsk, Izdaniye Ministerstva finansov Krasnoyarskogo kraya Publ., 2009. 262 p. (in Russian).

5. Kaufman I. I. Statistika gorodskikh sberegatel'nykh kass [Statistics of the city savings banks]. Saint Petersburg, V. Bezobrazov and K Publ. 1875. 110 p. (in Russian).

6. Kraevoye gosudarstvennoye kazennoye uchrezhdeniye «Gosudarstvennyy arkhiv Krasnoyarskogo kraya» (KGKU «GAKK») [State Archives of the Krasnoyarsk Territory]. F. 606. Op. 1. D. 1 (in Russian).

7. $K G K U$ «GAKK» [State Archives of the Krasnoyarsk Territory]. F. 606. Op. 1. D. 68 (in Russian).

8. $K G K U$ «GAKK» [State Archives of the Krasnoyarsk Territory]. F. 160. Op. 1. D. 1686 (in Russian).

9. $K G K U$ «GAKK» [State Archives of the Krasnoyarsk Territory]. F. 160. Op. 1. D. 2145 (in Russian).

10. $K G K U$ «GAKK» [State Archives of the Krasnoyarsk Territory]. F. 160. Op. 1. D. 2452 (in Russian).

Lushchaeva G. M., Siberian Federal University (pr. Svobodnyy, 82a, Krasnoyarsk, Russian Federation, 660041). E-mail: lusgalina@yandex.ru

Kondrat'eva A. A., Siberian Federal University (pr. Svobodnyy, 82a, Krasnoyarsk, Russian Federation, 660041). E-mail: nastyaalex010493@mail.ru 